\title{
La División Azul en el contexto de las relaciones entre la España de Franco y la Alemania nazi
}

\author{
Xavier MoReno JuLiÁ \\ Universidad Rovira i Virgili (Tarragona) \\ xavier.moreno@urv.cat
}

Recibido: 03/05/2012

Aceptado: 20/07/2012

\section{RESUMEN}

Cuando la División Azul nació, en junio de 1941, Franco hacía más de seis meses que había negado a Hitler su participación en la guerra. Las relaciones entre ambos países estaban en un momento muy bajo, a pesar de los muchos factores externos que puedan inducir a pensar lo contrario. Este trabajo parte, precisamente, de expectativas frustradas, para enlazar con lo que iba a significar la unidad: la aportación española a la lucha alemana. Pero limitada a Rusia y con objetivos muy propios, aunque Hitler llegase al punto de ver en su jefe al recambio idóneo en la cúpula del poder en España. Desencuentros, en fin, que quedan perfilados en las páginas que siguen, deudoras de muchos archivos públicos y privados, y que muestran la fragilidad de las interacciones entre franquismo y nazismo.

Palabras clave: Segunda Guerra Mundial, España, Alemania, Franco, Hitler, Muñoz Grandes, política, diplomacia, anglofobia.

\section{The Blue Division in the Context of the Interactions Between Franco's Spain and Nazi Germany}

\begin{abstract}
When the Blue Division started in June 1941, it had passed more than six months since Franco had refused Hitler his participation in the War. The relationships among both countries were in a very low moment, although many extern factors might bring us to think the opposite. This article assumes the frustrated expectations of what the Unity should mean: the Spanish contribution to the German fight. But the contribution was limited to Russia and it had very special objectives, although Hitler reached to see in its military chief the best replacement on the top of the power in Spain. Disagreements, at last, that remains profiled in the next pages, debtors of many Public and Private Archives. They show the fragility of the interactions between the Francoist regime and Nazism.
\end{abstract}

Key words: Blue Division, Spain, Germany, Franco, Hitler, Muñoz Grandes, politics, diplomacy, anglophobia.

Sumario: Introducción. 1. Interacciones hispano-alemanas antes de la configuración de la División Azul. 2. El ataque alemán a Rusia y la configuración de la División Azul. 3. Las interacciones hispanoalemanas durante el año 1941. 4. Las interacciones hispano-alemanas en el año 1942. 5. Muñoz Grandes: la alternativa alemana a Franco. 6. Las interacciones hispano-alemanas en el año 1943, la repatriación de la División Azul y epílogos frustrados. 7. Conclusiones. 8. Bibliografía. 


\section{Introducción $^{1}$}

Referir las relaciones entre la España de Franco y la Alemania de Hitler, en general, supone entrar en un mundo de complejidades, donde cabe no perder de vista los matices, en tanto que, en contra de lo que podría parecer lógico, los elementos que las definen no suelen responder plenamente a estructuras ideológicas, económicas, sociales o políticas. Más bien fueron realidades coyunturales las que generaron respuestas que, por razón de la evolución de la guerra, acabaron en un callejón sin salida. Fue, por tanto, en un contexto tan particular como aquél, que se desarrollaron las interacciones en torno a la División Azul y cuantos elementos la acompañaron.

Adolf Hitler nunca fue franquista: prefería Franco a la República. Nada más. Como ha quedado bien probado por la historiografía, se entendía a sí mismo como una especie de revolucionario y veía en Franco a un vulgar militar conservador con poder, como tantos en la Europa de entonces. En el fondo, desde la perspectiva de sus muchas frustraciones -obsérvese que a su uniforme militar unía corbata-, lo menospreciaba. Él, un hombre de partido, convencido de que había llevado a cabo una especie de revolución que había transformado radicalmente Alemania, y que en aquellos momentos transformaba Europa, entendía que muy poco tenía ante él: un militar africanista que a nada habría llegado de no haber sido por sus aviones, vitales para poder cruzar el Estrecho.

Franco estaba agradecido a Hitler por su apoyo durante la guerra civil, que quedó a deber. ${ }^{2}$ Pero, como su concuñado y ministro, Ramón Serrano Suñer, se sentía mucho más cercano a Benito Mussolini (a quien también había quedado a deber la ayuda material recibida). ${ }^{3}$ Ser mediterráneo unía y más si frente a ellos se alzaba una cosmovisión germánica, y para más inri, radicalizada. De todas maneras, no cabe la menor duda de que Franco fue "hitleriano de interés» durante una temporada. Pero ni de lejos los seis años de la guerra: sólo seis meses, entre abril y octubre de 1940, desde el inicio de la campaña occidental alemana y la entrevista de Hendaya. Con Hendaya, llegó el gran batacazo: los sueños imperiales (aunque ya puestos en entredicho por los informes llegados de Berlín de puño y letra de Serrano) quedaron deshechos en un día. Hitler, temeroso de una posible reacción favorable a la Inglaterra de Churchill, no había accedido a desvestir a la Francia derrotada de su imperio norteafricano en favor de España y, sólo por Gibraltar, exigía la entrada española en la guerra.

1 El texto utiliza las abreviaturas siguientes: PAAA (Politisches Archiv des Auswärtigen Amts, Archivos Políticos del Ministerio Alemán de Asuntos Exteriores), BM (Deutsche Botschaft Madrid, Embajada alemana en Madrid), ADAP (Akten zur Deutschen Auswärtigen Politik, 1918-1945, Actas sobre la Política Exterior Alemana, 1918-1945), StS (Büro des Staatssekretär, Oficina del Secretario de Estado del Ministerio Alemán de Asuntos Exteriores).

2 Para el inicio de las relaciones Franco-Hitler, sigue siendo fundamental la clásica obra del profesor Ángel VIÑAS: La Alemania nazi y el 18 de julio, Madrid, Alianza Editorial, 1974. Agradezco a mis queridos amigos el doctor Theodor Gehling, ya fallecido y en su día subdirector de los Archivos Políticos del Ministerio Alemán de Asuntos Exteriores, y a su esposa Christel, el habérmela regalado.

3 Para las interacciones Franco-Mussolini, a mi entender, la mejor obra sigue siendo la del finado profesor Javier TUSELL y de su esposa Genoveva GARCÍA QUEIPO DE LLANO: Franco y Mussolini. La politica española durante la segunda guerra Mundial, Barcelona, Planeta, 1985. También cabe destacar la obra de Morten HEIBERG: Emperadores del Mediterráneo. Franco, Mussolini y la guerra civil española, Barcelona, Crítica, 2004. 
Veamos, a continuación, cómo se hilvanó aquel capítulo de egoísmos mal gestionados entre España y Alemania, a partir del análisis de las interacciones habidas antes de la configuración de la División Azul (apartado 1), así como las desarrolladas a partir de su génesis (apartado 2) y durante el desarrollo de su actuación en Rusia (apartados 3, 4 y 6). A lo que añadiremos algunos aspectos relacionados con ella que incidieron de forma especial en el ámbito de los silencios y de las medias verdades, como fue el caso de la actitud del general Agustín Muñoz Grandes respecto a la postura a adoptar frente a Berlín (apartado 5). ${ }^{4}$

\section{Interacciones hispano-alemanas antes de la configuración de la División Azul}

Caídos los Países Bajos, Bélgica y Luxemburgo en mayo, e invadida Francia, los meses de junio, julio, agosto, septiembre y octubre de 1940 quedaron definidos por el ofrecimiento de Franco a Hitler de entrada de España en la guerra. En julio, momento de intensidad máxima y a ritmo casi vertiginoso, marcaron dicho proceder un conjunto de fechas que pasamos a detallar. el 4: El ministro español de Asuntos Exteriores, coronel Juan Beigbeder, manifestó al embajador Eberhard von Stohrer las demandas españolas. Concretamente: Gibraltar, Tánger, el Marruecos Francés y una rectificación de fronteras en la Guinea Ecuatorial. El 10: entrada de Italia en la guerra (Mussolini, tras no pocas dubitaciones, finalmente había optado por lo que su yerno, y ministro de Exteriores, Galeazzo Ciano había intentado evitar). ${ }^{5}$ El 12: España dejó de ser neutral y pasó a ser «no beligerante» (o sea, abiertamente decantada hacia uno de los beligerantes; en este caso, el Eje). El 14: una vez negociado con Gran Bretaña y Francia, España ocupó Tánger, ciudad sujeta desde 1922 a un estatuto que le daba la particular condición de internacional. El 16: horas antes de que el presidente francés Paul Reynaud fuese sucedido en el cargo por el mariscal Philippe Pétain y cientos de kilómetros más al norte, en el castillo belga de Acoz, el general Juan Vigón entró entregó a Hitler una carta de Franco con la siguiente frase: «No necesito asegurarle cuán grande es mi deseo de no permanecer reservado ante sus inquietudes». El 17: cuando Madrid iba a proceder a la ocupación del Protectorado francés, con la excusa de que, como potencia de la zona, estaba obligada a actuar y mantener el orden en la totalidad del territorio marroquí, recibió un mensaje del Gobierno francés. Pedía su intermediación con Berlín para llegar a un alto el fuego inmediato. En consecuencia, quedó suspendida la operación. El 19: el embajador español en Berlín, almirante Antonio Magaz, entregó al secretario de Estado alemán, barón Ernst von Weizsäcker, una nota con el ofrecimiento explícito de entrada en la guerra. Decía: «Si Gran Bretaña continúa en la guerra después de que Francia haya dejado de luchar, España podría

4 Para las figuras contrapuestas de Hitler y Franco, véase PAYNE, Stanley G.: Franco y Hitler. España, Alemania, la Segunda Guerra Mundial y el Holocausto, Madrid, La Esfera de los Libros, 2008, y MORENO JULIÁ, Xavier: Hitler y Franco. Diplomacia en tiempos de guerra (1936-1945), Barcelona, Planeta, 2007.

5 Para la persona y actuación de Mussolini, resultan fundamentales las biografías de J. B. BOSWORTH, Richard: Mussolini, Barcelona, Península, 2003 y CLARK, Martin: Mussolini. Personalidad y poder, Madrid, Biblioteca Nueva, 2007. En cuanto a Ciano, recomiendo su Europa hacia la catástrofe, Barcelona, José Janés editor, 1949, en tanto que, como sabemos, sus Diarios, Barcelona, José Janés editor, 1946, y Barcelona, Crítica, 2003, obra sin duda importante, lamentablemente fueron alterados en su contenido. 
entrar en ella después de un corto período de preparación de la opinión pública». A cambio, pedía los territorios antes referidos. Pero, por suerte para los españoles, Hitler estaba demasiado ocupado en gestionar su triunfo sobre Francia. «El Gobierno del Reich agradece muy cálidamente la actitud española», fueron las palabras alemanas a Franco el 25 de junio de 1940. Nada más.

Pero las cosas cambiaron el 31 de julio. Aquel día, decidido a atacar Rusia y ante la incapacidad de su marina de guerra para desembarcar tropas en el sur de Inglaterra, Hitler hubo de replantear su estrategia de guerra: necesidad de control de Gibraltar $\mathrm{y}$, al objeto de frenar un eventual ataque anglosajón por el oeste, establecimiento de bases en una de las islas Canarias. ${ }^{6}$ Le resultaba imprescindible, pues, que España entrase en la guerra. Y con ello, se abrió un nuevo capítulo en la relación entre ambos países, de modo que todo el mes de agosto y la primera quincena de septiembre fueron un continuo movimiento de jefes militares y diplomáticos alemanes en España.

Franco, halagado, decidió que la negociación no la llevase el titular de Exteriores, coronel Juan Beigbeder, sino Serrano Suñer, que a su condición de familiar indirecto, de ministro de la Gobernación y de abogado del Estado, unía un servicio impagable materializado unos años atrás (abril de 1937): haberle facilitado el control de la díscola Falange por medio del llamado Decreto de Unificación. A Berlín llevaba la oferta de la entrada de España en la guerra a cambio de la ya referida cesión territorial. Pero las entrevistas que mantuvo con Hitler y su ministro de Exteriores, Joachim von Ribbentrop, entre los días 15 y 25 de septiembre, fueron un fracaso. Hitler en modo alguno quería entregar territorios franceses a España pues, como ya se ha apuntado, temía una defección del ejército colonial francés a la causa británica. Además, del 23 al 25 tropas francesas frustraron un intento de desembarco degaullista en la africana Dakar, cosa que no tan sólo le reafirmó en su decisión, sino que lo llevó a considerar la posibilidad de configurar "una gran coalición" europea (Alemania, Italia, España y Francia) contra Gran Bretaña. El hecho es que el 25 Serrano Suñer marchó de Berlín sin haber llegado a acuerdos concretos y con no poca frustración. Dos días después, el 27, Alemania, Italia y Japón firmaron el Pacto Tripartito, ampliación del Pacto de Acero, de mayo de 1939.

El 23 de octubre de 1940, Hitler y Franco se reunieron en Hendaya. La reunión resultó un fracaso simple y llanamente porque Hitler se negó a las peticiones coloniales de Franco. Gibraltar era demasiado poco para justificar un paso tan arriesgado de éste como era la entrada en la guerra. Resultado de todo ello fue la presentación, por parte alemana, de un Protocolo Secreto, que sería redactado en tres ocasiones: el mismo 23 de octubre, en Hendaya; el 24, en el Palacio de Ayete, en San Sebastián, y el 11 de noviembre, en que finalmente se firmó, en Viena (al día siguiente Hitler firmaba el Plan Félix, de conquista del Peñón). El Protocolo señalaba la futura entrada de España en la guerra, pero no fijaba la fecha, lo que iba a permitir poco después a Franco desvincularse de él. Efectivamente, después de un frustrante segundo viaje de Serrano Suñer a Alemania (Berchtesgaden, «Nido de las Águilas»), los días 17, 18 y

6 Para los planes de Hitler para las Canarias, Marruecos y sus deseos de ampliación territorial hacia el oeste, véase GODA, Norman J. W.: Y mañana... el mundo. Hitler, África Noroccidental y el camino hacia América, Madrid, Alianza Editorial, 2002. 


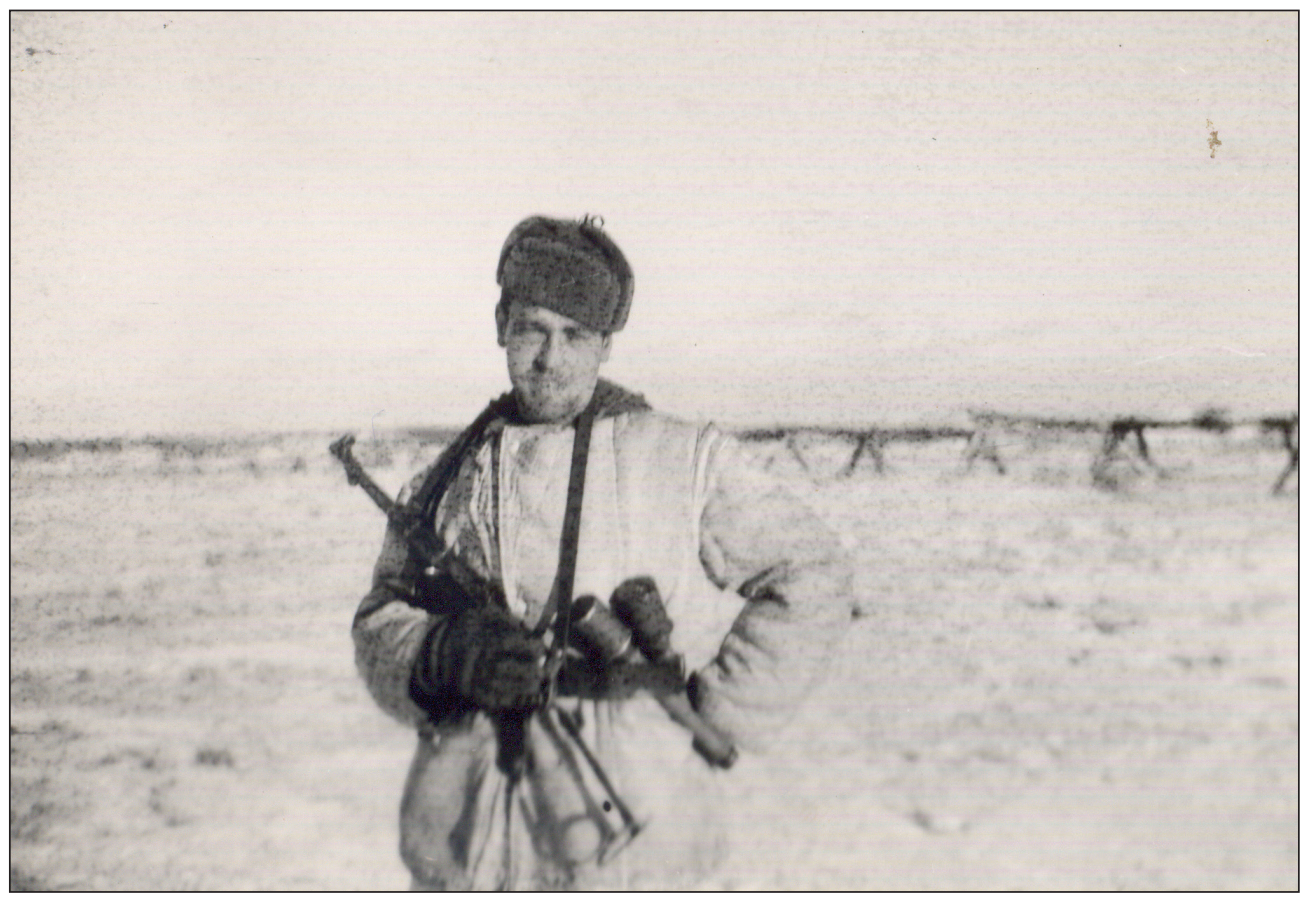

Oficial, traje de invierno. Archivo Rodríguez Jiménez

19 de noviembre, en el que Hitler y Ribbentrop mantuvieron su postura de no cesión territorial africana y manifestaron su deseo de configurar la referida coalición continental antibritánica, Franco decidió plantarse. Y fue el 7 de diciembre de 1940 cuando dijo «no» a la entrada en guerra. Concretamente, en la reunión que mantuvo con el almirante Wilhelm Canaris, llegado de incógnito a Madrid, que había de establecer el ataque a Gibraltar para el día 10 de enero. Franco, con su particular parsimonia, se limitó a argumentar que «España no estaba suficientemente preparada» para ello. Poco pero suficiente: todo había acabado. Llegada la comunicación a Berlín, Hitler se vio en la desagradable tesitura de tener que clausurar Félix. ${ }^{7}$

Hitler, poco acostumbrado a los «no», no podía aceptar sin más aquello. ${ }^{8} \mathrm{Y}$ aunque escribió a Mussolini un «Estoy muy triste por esta decisión de Franco», no cesó en el

7 Todos estos aspectos han quedado perfectamente sintetizados en ROS AGUDO Manuel: Franco/Hitler 1940: de la Gran Tentación al Gran Engaño, Madrid, Arco Libros, 2009. El profesor Agudo desarrolla con mayor amplitud el tema en La guerra secreta de Franco (1939-1945), Barcelona, Crítica, 2002, y La gran tentación. Franco, el Imperio Colonial y los planes de intervención en la Segunda Guerra Mundial, Madrid, Styria, 2008.

8 A juicio del autor, para la comprensión de la particular psicología de Adolf Hitler (1889-1945) resultan fundamentales, además de sus autobiografías (Mein Kampf; Munich; dos tomos: Mein Kampf. Eine Abrechnung, 1925, y Mein Kampf. Die nationalsozialistische Bewegung, 1927. Y Zweites Buch; Munich, 1928), las transcripciones de algunas de sus conversaciones privadas (Hitler's secret conversations 1941-1944; Nueva York, 1953) y los fragmentos de conferencias militares (Hitlers Lagebesprechungen. Die Protokollfragmente seiner militärischen Konferenzen 1942-1945; Stuttgart, 1962). Pero contamos, además, con muchas biogra- 
empeño de presión, hasta el punto de que Ribbentrop llegó a la amenaza de invasión. Fue el 20 de enero de 1941 y por boca del prudente embajador von Stohrer: Franco disponía de 48 horas para dar el «sí» a la entrada en la guerra. Sin duda se trataba de un «farol», pues Hitler difícilmente estaba dispuesto a repetir la historia de Napoleón, y mucho menos con el proyecto de invasión de Rusia entre manos. Pero el 21, Ribbentrop reiteró la amenaza: «A menos de que el Caudillo decida inmediatamente unirse a la guerra de las potencias del Eje, el Gobierno del Reich no puede prever más que el final de la España nacional». Era un hombre poco cultivado y sin el más leve tinte de versatilidad, que, como suele acaecer en dichos casos, se equivocaba mucho, hasta el punto de que el único final que iba a haber sería el de su Tercer Reich. Desde su sillón, una vez más Franco esquivó la tromba de agua cuando el 23 recibió al embajador alemán: le dijo que «nunca» había perdido la voluntad de entrar en la guerra (falso), y que sólo su «sentido de responsabilidad» frente a España, dada su catastrófica situación económica, no lo había permitido «todavía». Obviamente, sabía mentir. ${ }^{9}$

Hitler había perdido la partida. El 6 de febrero escribió a Franco, y hasta cierto punto se añadió a la amenaza directa al apuntar que «España nunca tendrá más amigos que Alemania e Italia, al menos, por supuesto que venga una España diferente» ( $\sin$ Franco, se entiende). Una amenaza que, obviamente no le interesaba materializar. El hecho es que, a partir de entonces, delegó en Benito Mussolini, quien aceptó el papel de intermediación con poquísimas ganas, en tanto que no podía evitar ver a España como una potencial rival en su cada vez más frustrado deseo de dominio mediterráneo. La entrevista de Bordighera (12 de febrero), en la Riviera italiana, de nada sirvió: Franco y Serrano Suñer no pararon de quejarse de la racanería hitleriana y manifestaron no comprender a qué venía tanto temor a la previsible reacción francesa, nación que debía ser tratada como lo que era: país vencido. Y reiteraron que sólo irían a la guerra si recibían de Alemania las compensaciones norteafricanas solicitadas además de ayuda económica suficiente. Pero aquello no era más que polvo en el viento. Hitler, en su particular forma de proceder, no estaba dispuesto a ceder ni un ápice en nada. Además, al día siguiente (13 de febrero), Franco y Serrano Suñer se reunieron con el viejo mariscal Pétain en Montpellier, y sin tapujos le pidieron apoyo moral ante Hitler. (¡A Pétain, a quien querían arrebatar las colonias!) Temían -le dijeron- un intento de invasión alemana de España. Ya de retorno, en Madrid, Franco respondió a la carta de Hitler: era el 26 de febrero (¡habían pasado veinte días ya!), y lo hizo con la contundencia que, hasta cierto punto, le permitía saberse entendido por Mussolini y apoyado por Pétain. Era el final. ${ }^{10}$

\footnotetext{
fías, así como con gran número de estudios sobre el desarrollo histórico que propició. Entre ellos, destacamos los de los autores siguientes: TREVOR-ROPER Hugh R.: The Last Days of Hitler, Oxford, 1947, BULLOCK Allan: Hitler: A Study in Tyranny, Londres, 1952, y revisión, Nueva York, 1962. Hitler and Stalin: Parallel Lives; Londres, 1991, FEST Joachim: Adolf Hitler: Eine Biographie; Frankfurt am Main-Berlín-Viena, 1973, TOLAND John: Adolf Hitler, Nueva York, 1976, IRVING David: Hitler's War, Londres, 1977, HAFFNER Sebastian: Anmerkungen zu Hitler, Munich, 1978, y KERSHAW Ian: Hitler: 1889-1936. Hubris (Harmondsworth, 1998) y Hitler: 1936-1945. Nemesis, Nueva York y Londres, 2000.

9 En cuanto a la psicología y actuación de Franco (1892-1975) durante la Segunda Guerra Mundial, resultan fundamentales las obras de PAYNE Stanley: El régimen de Franco, 1936-1975, Madrid, Alianza, 1987; PRESTON Paul: Franco «Caudillo de España», Barcelona, Grijalbo, 1994, y TUSELL Javier: Franco, España y la Segunda Guerra Mundial. Entre el Eje y la neutralidad, Madrid, Ediciones Temas de Hoy, 1995. 10 Véase Xavier MORENO JULIÁ: Hitler y Franco..., pp. 199-208.
} 
Aquel mismo 26 de febrero, el príncipe Pablo de Yugoslavia fue derrocado, por haber firmado el día antes la adhesión del país al Pacto Tripartito. El nuevo jefe del Estado sería el príncipe Pedro, hijo del finado rey Alejandro, y el del Gobierno, el general Dusan Simovic. El príncipe Pedro dirigió una proclama al país y la alegría se apoderó de las calles. Hitler valoró todo aquello como un golpe de Estado en contra de los intereses alemanes (no se equivocó), y el 6 de abril de 1941 atacó Yugoslavia y bombardeó el puerto griego de El Pireo. ${ }^{11}$ Un nuevo frente de lucha se acababa de abrir para Alemania: el ataque a Rusia debería esperar cinco semanas, tiempo perdido y decisivo para el futuro desarrollo de las operaciones militares. Pero Gibraltar había dejado de ser, definitivamente, centro de atención para la febril mente de Adolf Hitler. ¡Franco y su régimen podían lanzar, por vez primera en meses, un suspiro de alivio!

\section{El ataque alemán a Rusia y la configuración de la División Azul}

En la madrugada del 22 de junio de 1941 la Wehrmacht atacó al Ejército Rojo y comenzó una despiadada guerra de conquista, vendida al mundo primero como de justa defensa frente a los deseos soviéticos de expansión territorial (manifestados, en parte, por Molotov en su viaje a Berlín y hasta cierto punto avalados por cierta concentración de tropas al otro lado de la frontera) y más tarde, entrado 1943, con la capitulación de Stalingrado, como dique de contención del comunismo. ${ }^{12}$ Hitler, aunque nervioso y desconocedor del potencial soviético (las cifras de material de guerra que barajaba el Estado Mayor alemán no respondían a la realidad), esperaba que todo iba a resultar fácil: en ocho semanas el triunfo estaría del lado alemán, pensaba. Además, contaba con el apoyo militar de los finlandeses al norte (mariscal Mannerheim) y de los rumanos (mariscal Antonescu) al sur. De hecho, aunque la decisión definitiva de ataque no llegó hasta 1940, toda la política exterior de Hitler se había movido en torno a su ulterior enfrentamiento con la Unión Soviética (el Pacto de No Agresión, firmado por Ribbentrop y Molotov el 23 de agosto de 1939, fue una realidad meramente coyuntural, que dejó libres las manos a Hitler durante algunos meses). El ataque alemán a Occidente queda explicado por la adhesión francesa a la política británica de enfrentamiento, que llevó a Londres y a París a declarar la guerra a Berlín (el premier Neville Chamberlain, pacifista por naturaleza, había quedado supeditado a los postulados de los sectores radicales de su partido -el Conservador-, con Churchill a la cabeza). En cuanto a Polonia, se había negado a permitir la construcción de la autopista y el ferrocarril que debería unir la Prusia Occidental con la Oriental, así como a la «devolución» de Danzig a Alemania; exigencias hitlerianas trabadas por la promesa de ayuda británico-francesa. Promesa no materializada que llevaría a la

11 Para los antecedentes y el desarrollo de la guerra en Yugoslavia resulta imprescindible la consulta del libro de SCHMIDER Klaus: Der Partisanenkrieg in Jugoslawien 1941-1944, E. S. Mittler und Sohn Verlag, Hamburgo, 2002. Agradezco al profesor Schmider su invitación a concurrir a la Academia Militar de Sandhurst en calidad de profesor invitado, para disertar sobre la División Azul y la política exterior española durante los primeros años cuarenta.

12 Recomiendo muy particularmente, al respecto, la lectura del capítulo quinto del libro de OVERY Richard, Russia's War, 1941-1945, Londres, Penguin Books, 1999 (1ª ed. 1998). 
Polonia renacida en 1918 a su degüelle en 1939 por Alemania ( 1 de septiembre) y la Unión Soviética (17 de septiembre), y que no recobraría su libertad hasta 1989. ${ }^{13}$

En contra de lo que pudiera pensarse, la mayor parte de los alemanes no estaban seguros de una rápida y contundente victoria alemana sobre Rusia, y cuando Alemania atacó prefirieron contener la respiración a hacer especulaciones. De hecho, la mayoría había deseado que la guerra hubiese concluido en 1940, tras la caída de Francia (momento en el que Hitler recibió el que iba a ser su último baño de multitudes) y la esperada de Gran Bretaña; por lo que aquellos meses de más, unidos al enfrentamiento a una potencia de extensión enorme hasta entonces amiga (Pacto Germano-Soviético), turbó muchos espíritus. En todo caso, interesa señalar aquí que Londres reaccionó inmediatamente y, después de haber callado ante la agresión soviética a Polonia en 1939, se convirtió en la única capital europea que oficialmente se opuso a la agresión alemana a la Unión Soviética en 1941. ${ }^{14}$ Entretanto, Madrid vivió la noticia de la invasión con lógica exaltación y, no sin tensiones, acabó por generar la División Azul. Veamos cómo.

A las seis de la madrugada del domingo 22 de junio, tres horas después de iniciado el ataque, la embajada en Berlín informó telefónicamente del evento a Serrano Suñer. Poco después, por deseo de Ribbentrop, el embajador Stohrer le telefoneó para comunicarle la decisión de invasión y los motivos que habían llevado a ella. Seguidamente, Serrano Suñer se dirigió a El Pardo, donde informó a Franco y le manifestó el deseo de Falange (de «su» Falange) de contribuir a la lucha con un contingente voluntario. Con ello no hacía otra cosa más que manifestarle cuanto él y su círculo íntimo, con Dionisio Ridruejo como figura más destacada, habían estado valorando para caso de que finalmente se produjese la confrontación. Franco, de entrada, no se opuso. A continuación, Serrano Suñer se dirigió a la Embajada alemana, en el Paseo de la Castellana, y comunicó a su apreciado Stohrer la decisión. Franco -le dijo- enviaría a Rusia «unas cuantas unidades» de voluntarios falangistas en reconocimiento a la

13 Agradezco a mis queridos amigos los profesores polacos Arkadiusz Adamczyk, Jan Ciechanowski, Patrycja Jacóbczyk-Adamczyk, Pavel Olszewski y Dariusz Rogut, y al doctorando Bartosz Kaczorowski, sus muchas gentilezas hacia mi persona en mis estancias académicas en Polonia. Agradezco también al profesor Radoslaw Zurawski vel Grajewski, de la Universidad de Lódz, mi inclusión en su magna obra sobre el papel de las autoridades europeas en el exilio. Y al investigador húngaro y buen amigo, doctor Tamás Stark, su generosidad.

14 De hecho, hacía tiempo que Londres estaba alerta: ya el 23 de abril de 1941, Churchill había ordenado preparar una fuerza expedicionaria a Portugal, para tomar las Islas Azores y las de Cabo Verde si el Eje invadía la Península Ibérica. Y el día siguiente, su estado mayor había propuesto movilizar fuerzas contra España mediante Puma, operación para ocupar una de las Canarias. Poco después, el estallido en Madrid de la crisis política del mes de mayo, que llevaría a José Luis de Arrese, José Antonio Girón y Miguel Primo de Rivera al Gobierno, había generado un detallado análisis por parte de las diplomacias alemana y británica. Ésta la valoró como un triunfo de Franco sobre Serrano Suñer, «bestia negra» del embajador Samuel Hoare. Y fue en Londres que, el 18 de junio, el embajador español, Duque de Alba (Jacobo Fritz-James Stuart y Falcó), supo, por boca del subsecretario del Foreign Office, de la concentración de tropas alemanas en la frontera con la Unión Soviética y de la posibilidad del inicio de una guerra. Para la acción británica frente a España durante la Segunda Guerra Mundial, véase la excelente obra de MORADIELLOS Enrique: Franco frente a Churchill. España y Gran Bretaña en la Segunda Guerra Mundial (1939-1945), Barcelona, Península, 2005; así como las de WIGG Richard: Churchill y Franco. La politica británica de apaciguamiento y la supervivencia del régimen, 1940-1945, Barcelona, Debate, 2005, y BURNS MARAÑÓN Jimmy: Papá espía. Amor y traición en la España de los años cuarenta, Barcelona, Debate, 2010. 


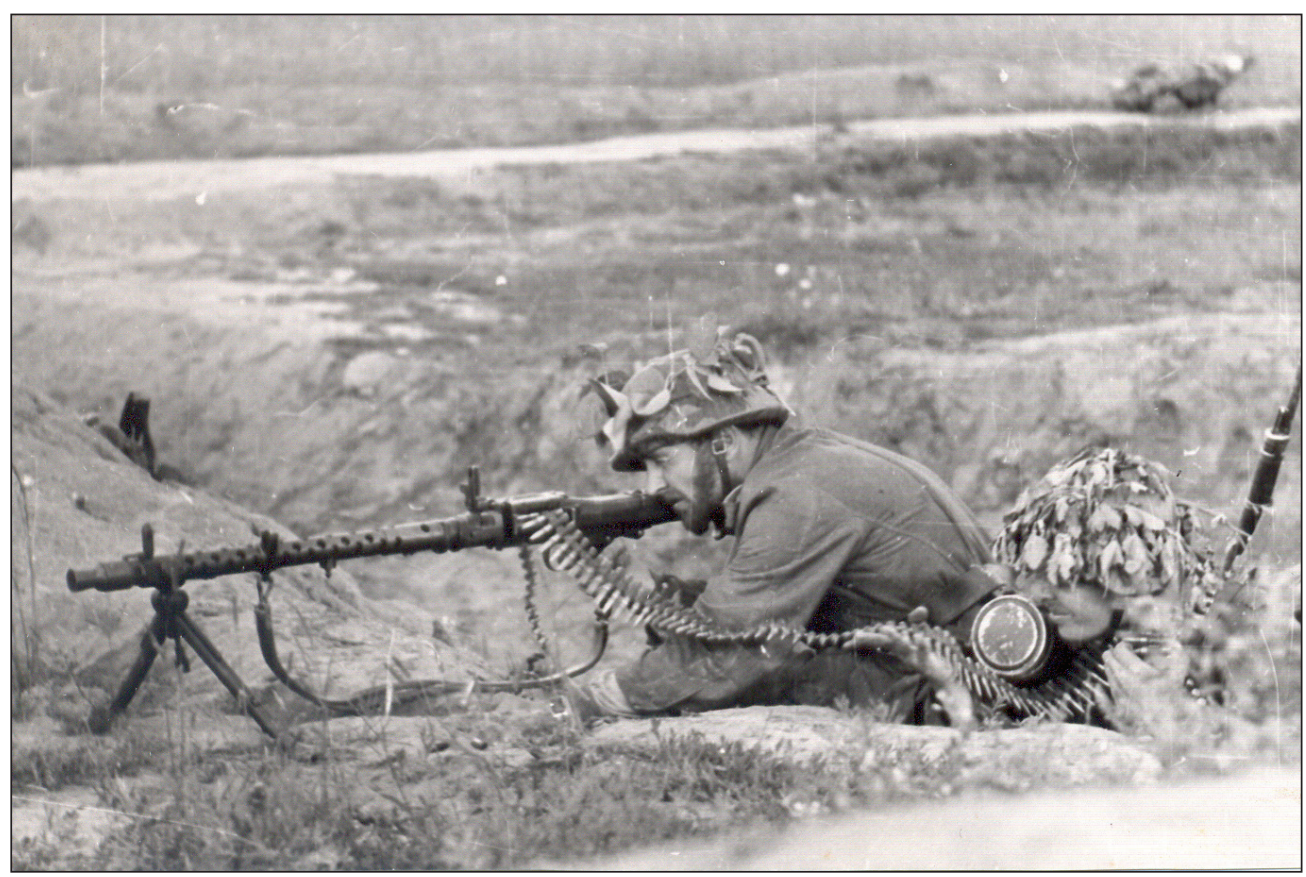

En las trincheras. Archivo Rodríguez Jiménez

ayuda recibida de Alemania durante la guerra civil, lo que -puntualizó- no debería entenderse como el anuncio de la entrada de España en la guerra. Al embajador, no le quedó más remedio que telegrafiar a Berlín y solicitar del Auswärtiges Amt (Ministerio de Asuntos Exteriores) las pautas a seguir ante aquel ofrecimiento. ${ }^{15}$

Pero el lunes 23, el Ejército impuso a Franco su participación en la guerra germano-soviética. Había bastado un día para triturar el proyecto falangista. Obviamente, Serrano Suñer y los suyos quedaron más que frustrados, y en el Consejo de Ministros que comenzó aquella tarde, el ministro se enfrentó al general Enrique Varela Iglesias ${ }^{16}$, titular del Ejército y simpatizante del carlismo, para, por lo menos, preservar el carácter voluntario de la unidad (llegó al extremo de llamarle «tonto»). Y mientras la prensa filtraba al país la posibilidad de configurar una unidad de voluntarios «contra el bolchevismo», la Falange tenía ya -una vez más- la partida perdida frente al Ejército. ${ }^{17}$

15 Para parte de los aspectos vertidos en este artículo véase MORENO JULIÁ Xavier: La División Azul. Sangre española en Rusia, 1941-1945, Crítica, Barcelona, 2004. Hay traducción al polaco (Zélow, ATENA, 2009). El apartado del presidio español en Rusia había dado lugar previamente al artículo «Repatriacja hiszpanskich jenców wojennych więzionich w Związku Sowieckim», en el libro Represje sowieckie wobec narodów Europy 1944-1956, Zélow, ATENA, 2005, pp. 369-383.

16 Agradezco a los señores Jaime Barriuso y Miguel García Díaz el haberme cedido copia del archivo del general Varela.

17 Para la realidad del falangismo de postguerra véase la obra del profesor Joan Maria Thomàs, fundamentalmente: La Falange de Franco. Fascismo y fascistización en el régimen franquista (1937-1945), Madrid, Plaza y Janés, 2001. 
Finalmente, Berlín reaccionó. El martes 24 Ribbentrop telegrafió a Stohrer la aceptación del voluntariado español y la petición de que intentase arrancar de Madrid el compromiso de declaración de guerra a la Unión Soviética: dicho en otras palabras, que España entrase abierta y formalmente en la contienda, algo evidentemente imposible después del fracaso de Hendaya y el «no» de Franco de diciembre del año anterior. En cuanto a éste, impuso el mando militar a la que sería la División Azul (Muñoz Grandes simpatizaba con el falangismo por haber ocupado la Secretaría General del Partido, pero no era falangista) y, con ello, desvertebraba definitivamente toda veleidad de predominio falangista en su seno. Por su parte, el embajador Stohrer se reunió con Serrano Suñer y comprobó lo que ya temía, que no habría entrada española en la guerra, en cuanto el ministro manifestó su temor a la posibilidad de un bloqueo comercial por parte anglosajona, y afirmó que transmitiría a Franco el deseo alemán pero que veía muy difícil su materialización. A continuación hubo los sucesos de la calle de Alcalá: varios centenares de falangistas vociferando contra Rusia por varias arterias madrileñas y, una vez allí, Serrano Suñer, desde el balcón de la Secretaría General de Falange, los arengó al grito de «¡Rusia es culpable!»». ${ }^{18}$

Entre el 27 de junio y el 2 de julio de 1941 se materializó la recluta para la División Azul, tanto a nivel de Falange como del Ejército. Salvo en Cataluña, donde no fueron aceptados los carlistas, y el País Vasco, donde los carlistas no unificados se negaron a inscribirse, la recluta civil fue un éxito, hasta el punto de que en Madrid y algunos otros puntos de Castilla sobrepasó en mucho el límite exigido. En cuanto a la militar, constituyó también un éxito pues la milicia proveía fundamentalmente de oficialidad deseosa de promoción. Hubo incluso soldados que cubrieron los vacíos civiles, igual que falangistas valencianos completaron la falta de sus homólogos catalanes. Y fue el último día, miércoles 2 de julio, que Serrano Suñer volvió a ocuparse de Alemania y de dejar las cosas meridianamente claras por medio de una cuidada entrevista al corresponsal en Madrid de la Deutsche Allgemeine Zeitung, en la que manifestó que España tomaría parte en la guerra «moral» en contra de la Unión Soviética, «el más odiado de los enemigos del pueblo español».

\section{Las interacciones hispano-alemanas durante el año 1941}

Del 13 al 22 de julio de 1941 tuvo lugar el transporte escalonado de voluntarios hacia Baviera, en diecinueve expediciones. Y ya el 17, comenzó la acción alemana de entreno de los divisionarios en el campamento militar bávaro de Grafenwöhr, que, con sus más y sus menos, acabó el 19 de agosto. Allí, Muñoz Grandes había creado un Servicio de Información para localizar y actuar contra "desafectos, murmuradores

18 Posteriores incidentes promovidos por una parte de los manifestantes frente a la embajada británica llevaron a Hoare y a varios de sus colaboradores a casa de Serrano Suñer y a él a echarlo, tras una invectiva del embajador, que calificó a España de «país de salvajes». Los desencuentros hispano-británicos, sin embargo, no acabaron aquí. El miércoles 25, baterías españolas del Campo de Gibraltar, bajo mando de Muñoz Grandes, dispararon a un avión británico que sobrevolaba Algeciras. Los británicos respondieron desde el Peñón, y los españoles replicaron. Podemos afirmar que probablemente aquel fue el punto de desencuentro máximo entre los dos países, movidos por el nerviosismo del momento. Al día siguiente, el Foreign Office decidió el embargo momentáneo de petróleo a España. 
[y] derrotistas", por medio de un sistema de células abiertas, esto es, de individuos seleccionados previamente que se desconocían entre sí. Temía que entre los «elementos disolventes» hubiese hombres del espionaje británico. Además, en Grafenwöhr las cosas no habían marchado bien del todo, pues el choque de mentalidades acabó por imponerse en las interacciones hispano-alemanas. Así, actitudes poco correctas por parte española, sobre todo con mujeres por medio (las camareras de las cantinas e incluso las acompañantes de alemanes) y el enfado y desprecio alemanes, con puñetazos y algún que otro disparo de pistola, marcaron unos días difíciles. Un conjunto de problemas que de hecho únicamente quedaron superados por la gran velocidad con que la tropa española quedó adiestrada: cuatro semanas. La División Azul participaría en la toma de Moscú y debía darse prisa, pensaba Muñoz Grandes. En la jura de bandera sus hombres habían prometido fidelidad a Hitler «en su lucha contra el comunismo» y convenía mostrar al mundo que aquello no eran meras palabras.

Así las cosas, el 20 de agosto de 1941 comenzó la marcha hacia Rusia que, dadas las muchas circunstancias a las que tuvo que hacer frente (nueve días en tren, treinta y uno de marcha a pie y otros trece en tren), no concluiría hasta el 11 de octubre. Unos días duros en los que hubo que hacer frente a una gran desilusión: Hitler, necesitado de tropas en el sector Norte del frente, y con malos informes sobre los españoles (deficiente uniformidad, poco cuidado de caballos y bicicletas, actitudes irrespetuosas...), así como el rechazo del jefe del 4 Ejército, capitán general Günther von Kluge, decidió que los españoles no irían a Moscú. Ni que decir tiene que la desilusión ganó el ánimo de todos después de muchos kilómetros ya andados (más de ochocientos), y aquella división hipomóvil meridional, la Blaue, cercana ya a Smolensk, hubo de dar marcha atrás casi cien kilómetros más, hasta Vitebsk, donde tomaría el tren hacia el norte, a Novgorod, donde había sido destinada y donde permanecería hasta agosto de 1942.

En octubre de 1941 las temperaturas en Novgorod se situaban ya por debajo de los cero grados centígrados. Iba a comenzar el invierno más frío de todo el siglo en Rusia y no había ropa de invierno porque la campaña, según las previsiones alemanas, debería haber acabado ya (de hecho, hasta febrero de 1942 el Ejército alemán no iba a ser provisto de ropa de invierno.) Por suerte para los españoles, la Sección Femenina había tejido algunas prendas de lana, pero no era suficiente.

Después de haber conseguido cruzar el río Voljov y de conquistar algunas poblaciones, parte de los españoles quedaron frenados ante las localidades de Possad y Otenski, donde durante el mes de noviembre y la primera semana de diciembre pasaron un calvario defensivo, a temperaturas en torno a los treinta grados negativos y hasta los cuarenta. Sin equipo de invierno y ante un enemigo mejor pertrechado, sus muertos fueron muchos y las perspectivas de victoria quedaron en nada. ${ }^{19}$

Aquello respecto a la acción de las armas. Pero la diplomacia ni estaba ni había estado en mejores condiciones. Así, una primera queja española ante Alemania refirió la falta de comunicados sobre la División Azul, en aquellos momentos, de camino

19 Para la vertiente militar de la División Azul, el mejor libro sigue siendo: KLEINFELD Gerald R. y TAMBS Lewis A.: La División española de Hitler. La División Azul en Rusia, Madrid, Editorial San Martín, 1979. Agradezco al profesor Kleinfeld su afabilidad y gentileza durante las jornadas de trabajo que compartimos en Madrid en octubre de 2011. 
hacia el frente. La queja pasó de Madrid a Berlín de la mano del nuevo embajador allí, José Finat y Escrivá de Romaní, conde de Mayalde. Pero tal circunstancia no era cierta, en tanto que el Alto Mando de la Wehrmacht (OKW) informaba diariamente a los agregados militares de las embajadas. Y se daba la circunstancia de que la División española telegrafiaba diariamente al Estado Mayor Central, en Madrid. He aquí que la Embajada alemana llegase a la conclusión de que era el Ejército español (general Varela) el que, dadas las diferencias existentes, no pasaba la información al Ministerio de Asuntos Exteriores (Serrano Suñer).

Poco después, por deseo de Serrano Suñer, Finat pidió permiso para visitar a los heridos de la División Azul, lo que desagradó al Ejército alemán, demasiado centrado en la lucha para aceptar que el ámbito diplomático alterase ni un milímetro su foco de atención. Pero las presiones españolas dieron su fruto gracias a la labor del secretario de Estado, barón Ernst von Weizsäcker, y el embajador finalmente pudo emprender su viaje al frente. Así, tras tres días de accidentado viaje, llegó el 24 de octubre, tan sólo doce días después de la entrada en combate de la unidad. Lo acompañaba el agregado militar de la Embajada, teniente coronel José Roca de Togores. La visita fue breve, dado que sólo duró cuatro horas, pero suficiente para recibir explicaciones y peticiones de Muñoz Grandes, deseoso de camiones (los alemanes se negaban a cederlos), caballos (sólo durante la marcha, el regimiento de artillería, uno de los cuatro de la unidad, había perdido seiscientos de 2.300), ropa de abrigo (cada soldado, de entrada disponía sólo de una manta, ropa interior, camisa y guerrera) y café.

A finales de noviembre, Serrano Suñer inició su tercer y último viaje a Alemania. Un viaje meramente protocolario, en tanto que de asistencia a la ceremonia de renovación del Pacto Antikommintern, firmado cinco años antes. Tuvo lugar entre el 24 y el 29 de noviembre de 1941, día en que se reunió por última vez con Hitler. Fue un encuentro mucho más relajado que los anteriores, en tanto que España había quedado al margen de la guerra general, y su acción quedaba limitada al frente ruso y sin declaración de guerra. En ella, Serrano Suñer reafirmó la dependencia económica española de los aliados. La economía, dijo, era un obstáculo para una política exterior «audaz». Y ante una pregunta de su interlocutor, se mostró favorable a contribuir en la defensa de las islas Azores frente a un eventual ataque anglosajón. Seguidamente, refirió el deseo español de «sincera amistad» con Alemania, afirmación que aprovechó para entrar en la cuestión de la División Azul: solicitaba la repatriación de varios falangistas de renombre con el argumento de que tenían «labores importantes» a desarrollar en España, fundamentalmente -dijo-, «promocionar la amistad con Alemania y fortalecer el Gobierno de la nación». Obviamente nada de aquello era verdad: el deseo de retorno sólo respondía al miedo a perderlos por muerte. Hitler aceptó y, acto seguido, acordaron también proceder a un cierto relevo de efectivos con hombres llegados de España. Más tarde, Serrano Suñer reiteró ante Ribbentrop su deseo de visitar la División Azul, e indicó que esperaba poder hacerlo a principios de enero. Ribbentrop se limitó a contestar que comunicase con antelación suficiente la fecha prevista al objeto de tenerlo todo preparado.

Hasta aquí las reuniones de alto nivel. Por lo que a otros aspectos de aquel viaje respecta, referir que, durante el transcurso de la firma de renovación del Pacto Antikomintern, Serrano Suñer hizo un discurso en el que se refirió a la División Azul, 
«prueba fehaciente del entusiasmo del soldado español, que se siente orgulloso de marchar entre las filas de los ejércitos de Europa, con sus antiguos y nuevos hermanos de armas, para participar en la heroica cruzada ante el mayor enemigo de la humanidad». Hizo también una visita a la mansión de Göring, quien durante años había sido considerado segundo de Hitler, pero que después de su fracaso aéreo sobre Inglaterra -era aviador y jefe de la Luftwaffe- estaba de capa caída y se dedicaba al robo de obras de arte de los países ocupados (en su «currículum» destacaba el haber hecho los primeros decretos de actuación contra los judíos.) Y visitó también el Hotel Kaiserhof, así llamado en tributo a la figura del káiser (el último emperador de Alemania, Guillermo II, acababa de morir en los Países Bajos -4 de junio-, donde se había refugiado al acabar la Primera Guerra Mundial y donde, después de la muerte de su nieto, príncipe Guillermo, en acción de guerra, había renegado de Hitler y los suyos.) Pero, a pesar de aquellas visitas de cortesía, el ambiente general del viaje resultó muy pesado. Las cosas en Rusia no marchaban nada bien, hasta el punto de que, tan sólo unos días después, el 5 de diciembre, la guerra allí iba a cambiar de signo. ${ }^{20}$ No había, pues, ni de lejos, el optimismo (algo histérico, eso sí) que había habido durante el verano. Así, el discurso de Ribbentrop en el Kaiserhof manifestó que el ruso era «un adversario tenaz», que luchaba «con una entrega increíble» y con «un material de guerra incalculable», lo que era verdad.

Serrano Suñer retornó a España. Estaba satisfecho: había logrado acuerdos y en aquel momento acababa de recibir honores por parte alemana en el puente internacional de Hendaya y ahora los recibía de fuerzas españolas. Ya en Madrid, el embajador Stohrer recogió su deseo de visitar la División Azul y contactó con Ernst von Weizsäcker, el secretario de Estado. De momento no llegó la respuesta, y a principios de diciembre reemprendió la cuestión y le preguntó si, de llevarse finalmente a término el viaje, él habría de acompañar al ministro. Weizsäcker consideró positiva su inclusión y trasladó la cuestión a Ribbentrop, quien ordenó llevar a cabo las pertinentes gestiones ante los mandos militares. Pero, dada la desfavorable evolución de la lucha, éstos se mostraron contrarios a acceder a la petición. Una vez que Serrano Suñer supo de la negativa por boca de Stohrer, presionó a Finat para que, por lo menos, obtuviese el traslado a Alemania de sus amigos, los divisionarios falangistas Dionisio Ridruejo y Agustín Aznar, en aquellos momentos hospitalizados. Ridruejo, con un cuadro agudo de agotamiento y descalcificación, y Aznar, con un tobillo fracturado, finalmente pudieron recuperarse en Berlín, al amparo de la Embajada española, en un contexto de privilegio. ${ }^{21}$

20 Aquel día, las tropas del general Georgi Zhukov, llegadas de Siberia, salieron de Moscú y arramblaron la vanguardia alemana, inmóvil desde hacía días por incapacidad de funcionamiento de los tanques y los vehículos. Las temperaturas habían llegado a 37 grados centígrados bajo cero. La guerra había acabado de cambiar de signo, hasta el punto de que la ofensiva alemana de 1942 quedaría limitada a un sector del frente, en la búsqueda de petróleo, mientras que 1943 sólo vería un pequeño avance en el sector central de Kursk, rápidamente neutralizado por el Ejército Rojo. La guerra estaba decidida ya en contra de Alemania desde el desastre de Stalingrado, en enero, cuando un ejército entero, el 6, resultó eliminado (210.000 hombres muertos y 90.000 apresados, de los que sólo cinco mil retornarían a Alemania después de diez años de cautiverio).

21 A nivel de libros, véanse los aspectos sociopolíticos de la División Azul en RODRÍGUEZ JIMÉNEZ José Lui: De héroes e indeseables. La División Azul, Madrid, Espasa, 2007, y MORENO JULIÁ Xavier: La División Azul... 


\section{Las interacciones hispano-alemanas en el año 1942}

Durante el invierno de 1941 a 1942, la División Azul, acantonada en la zona del río Voljov, tuvo que hacer frente a un doble ataque soviético: al norte, del Frente Noroeste, del general Pavel Kurotchkin, y al sur, del Frente Voljov, del general Kirill Meretskov. En el primer caso, la compañía de esquiadores quedó deshecha, en tanto que perdió 216 hombres de 228, en el intento de rescate de alemanes al otro lado del lago Ilmen. Y con respecto al sector sur, tres ejércitos soviéticos irrumpieron en Teremets (enero) y en Bol y Mal Samoschje (febrero), puntos donde la División Azul tuvo que emplearse intensamente y no sin bastante éxito.

Llegada la primavera, Alemania seguía a la defensiva en Rusia, pero Hitler preparaba la que habría de ser la ofensiva definitiva. El 15 de marzo, en su tradicional discurso conmemorativo del Heldengedenktag (Día de Conmemoración de los Héroes), aseguró que la victoria llegaría en el verano. Pero una cosa era lo que decía y otra lo que hacía. Así, su Directriz número 41, de 5 de abril, limitó la ofensiva al sector sur del frente y hacía del petróleo del Cáucaso su objetivo principal. En el sector central, la Wehrmacht permanecería a la defensiva, en tanto que en el norte, reprendería el ataque a Leningrado. En cuanto a la División Azul, aquella primavera tomó parte en las acciones de «limpieza» al oeste del rio Voljov, donde quedarían aprisionados los 130.000 hombres del general Andrei Vlasov, no sin antes haber generado más de un susto a los españoles (ataque de tanques en Kutrik, el 2 de abril). Llegado el mes de marzo, todos los regimientos de infantería alemanes quedaron reducidos en un treinta por ciento, por lo que las divisiones dejaban de tener nueve batallones y pasaban a tener sólo seis. Todas, menos una: la Azul, la única del Ejército alemán que mantendría su configuración inicial y, por tanto, la mayor de cuantas Hitler tendría. Entonces, la Wehrmacht desencadenó en Crimea un primer ataque preliminar, forzó el paso del río Donetz y consiguió una posición en su vertiente norte. La ofensiva general dio comienzo el 28 de junio, ya en verano. El 6 de julio caía Sebastopol. El éxito parecía sonreír a Alemania, pero aquella sería una sonrisa fugaz. La última.

Llegado agosto, la División Azul cambió de frente. Concretamente emprendió la marcha hacia el norte, a la región de Kolpino, barrio de Leningrado, para tomar parte en el asalto a la ciudad (Operación Luz del Norte). Pero allí quedaría bajo la acción de la artillería rusa, de una gran potencia, y una vez clausurado el proyectado ataque (16 de octubre), la lucha se convertiría en una batalla de posiciones. En aquella situación, a finales de año, Muñoz Grandes sería relevado por el general Emilio EstebanInfantes, y tendría una tercera y última reunión con Hitler (13 de diciembre), que le pediría garantías del Gobierno español del empleo del armamento que le facilitaría contra los aliados en el caso de que intentasen desembarcar en la Península Ibérica. Pero por entonces, la guerra había cambiado ya de signo: la derrota alemana de El Alamein, en Egipto, el desembarco anglosajón en Marruecos y Argelia (Operación Torch), y el cerco soviético sobre el 6 Ejército en Stalingrado se habían consumado el mes anterior. Ni la ocupación de la Francia de Vichy y Córcega por Hitler, ni el establecimiento de una cabeza de puente en Túnez iban a poder cambiar nada ya.

Mientras todo aquello ocurría en el frente, la retaguardia hispano-alemana estaba en plena ebullición. El año se había abierto en España con malos presagios con res- 
pecto a la División Azul. El discurso radiado de Muñoz Grandes en el día de Año Nuevo no había dejado lugar a dudas, al manifestar que «los tiempos eran críticos y difíciles» y que «el enemigo era duro y que muy duro era también el invierno ruso». Los muertos eran ya muchos, y la prensa y la radio se hacían eco de las pérdidas. A nadie escapaba que la situación bélica era, como mínimo, difícil.

Frente a una situación como aquélla, en enero Serrano Suñer se mostró muy interesado en la repatriación del cadáver del eximio falangista madrileño Javier García Noblejas. Era para él una cuestión de principios, pero también de rentabilidad política de la mano de un sepelio multitudinario. Y se puso manos a la obra con la colaboración de Ramón, repatriado del frente ruso y único de los hermanos Noblejas todavía vivo, y del embajador Stohrer, que telegrafió a Berlín en diversas ocasiones. Pero la primera respuesta fue negativa: la posibilidad técnica del traslado era dudosa en tanto que no se sabía el punto donde estaba enterrado. Pero dado que Madrid argumentó que la División Azul conocía perfectamente el emplazamiento, a mediados de febrero llegó una segunda respuesta, que fue definitiva: Muñoz Grandes había dicho «no» a la repatriación. Aquélla era probablemente la venganza del general ante Serrano Suñer, quien en su día lo había eliminado de la jefatura de la Secretaría General del Movimiento.

Pero lo que mayores problemas diplomáticos iba a generar durante el primer trimestre de 1942 fue la petición española de descanso de la unidad. Ya el 2 de enero, un miembro de la diplomacia paralela alemana, el llamado Dienstelle Ribbentrop, Erich Gardemann, había manifestado a Stohrer que, siguiendo la forma de proceder de la Legión Cóndor, Franco quería una rotación regular de hombres en la División Azul. Aquello, según había manifestado el general Moscardó -dijo Gardemann- afectaría a un contingente de entre dos mil y dos mil quinientos hombres cada tres o cuatro meses. Una semana después, el 10 de enero, Finat manifestó a Weizsäcker que, «por razones morales y políticas» Franco deseaba que la División Azul fuese retirada «durante algún tiempo» a retaguardia y, a ser posible, «reforzada» con tropas alemanas de reserva. Argumentó que aquellas medidas contrarrestarían la propaganda aliada, que afirmaba que había quedado diezmada, y que animarían a los sectores germanófilos españoles. Así las cosas, el 14 Hitler fue informado en Rastenburg, y después de consultar con algunos generales, manifestó que la situación militar imposibilitaba la retirada del frente. Cuando Madrid recibió la noticia, forzó a Finat a volver a la carga ante Weizsäcker. Los motivos para la retirada de descanso eran de peso, dijo que las bajas sumaban ya un tercio del contingente total, que le faltaban oficiales y que España tenía preparados refuerzos. Finalmente recorrió a un elemento efectista, de escasa verosimilitud: en la División Azul -dijo- había estaba la mayor parte de los estudiantes falangistas de Barcelona (probablemente no era verdad) y preocupaba al Gobierno que en aquellos momentos los estudiantes «rojos» controlasen su ambiente (falso). Weizsäcker envió un mensaje a Ribbentrop, de viaje en tren especial: convenía dar a los españoles -dijo- una respuesta por vía diplomática. Finalmente, dos semanas después, el 18, el Ejército manifestó que resultaba imposible sacar la División Azul de sus posiciones, y argumentó que su situación era privilegiada en tanto que disponía de una ciudad -Novgorod- para su acantonamiento. 
Cuando Finat supo la negativa, se puso muy nervioso: temía la reacción de Franco. Weizsäcker estaba tan preocupado como él y lo manifestó a Ribbentrop. Sin embargo, el ministro quiso saber si todo acababa con una petición de descanso o si, por el contrario, los españoles anhelaban la retirada del frente y la repatriación. Weizsäcker lo tranquilizó y consiguió entrar en contacto con el capitán general Alfred Jodl. Dos eran las soluciones posibles: o retirarla durante un tiempo, a unos cien o doscientos kilómetros del frente, o, en su defecto, permitir el gradual relevo de sus tropas. En aquellos momentos en Madrid había crispación. Según Serrano Suñer manifestó a Stohrer, las familias de los divisionarios - «las más germanófilas de España»- estaban «muy molestas», y más si se tenían en cuenta los relevos permitidos en su día a la Legión Cóndor. Además, el jefe del Estado Mayor Central, general Carlos Asensio (tiempo después sería ministro del Ejército), había enviado al agregado militar en Berlín órdenes para llevar a cabo un amplio relevo de tropa.

Finalmente, el 4 de marzo llegó la respuesta definitiva del OKW a la solicitud española: no habría pase a retaguardia, por imposibilidad militar, pero sí un relevo parcial de efectivos y, de autorizarlo Muñoz Grandes, también la solicitada repatriación de dirigentes falangistas. Informado Madrid, decidió que fuese el propio general Asensio quien se trasladase a Berlín para fijar los detalles del proceso. Ya allí, el jefe del OKW, mariscal Wilhelm Keitel ${ }^{22}$, le manifestó que el relevo se desarrollaría en tres etapas: la primera, para cubrir bajas, comenzaría inmediatamente, bajo la premisa de que habría que trasladar al frente unos tres mil hombres; la segunda, reemplazaría a unos mil, entre ellos, a los jefes falangistas requeridos, y la tercera, sustituiría casi a un tercio de la División Azul. Asensio, satisfecho, se trasladó a Könisberg para informar personalmente a Muñoz Grandes, quien mostró su extrañeza por la decisión de substitución, dado que, según dijo, lo único que verdaderamente necesitaba eran tres o cuatro mil hombres para cubrir las bajas habidas.

Durante aquellos días de marzo, otra dosis de aire fresco llegó para las diplomacias española y alemana. Fue el día 13, cuando Hitler concedió a Muñoz Grandes la Cruz de Caballero de la Cruz de Hierro, condecoración que muy pocos extranjeros llegaron a tener en transcurso de la guerra. Elemento irrelevante cara a su evolución pero de un gran valor en el ámbito de la propaganda, pues dio a la unidad una aureola de prestigio en Alemania y entre los medios germanófilos del resto de Europa. El Cuartel General de Hitler publicó:

Los voluntarios españoles, agrupados en una división, combaten en uno de los puntos más álgidos de nuestro frente. Los valientes combatientes españoles han rechazado a los atacantes soviéticos, causándoles grandes pérdidas. El alma de la resistencia de la División es su comandante, el general Muñoz Grandes. La defensa del sector, gracias

22 El mariscal Keitel y el capitán general Jodl fueron ejecutados, por sentencia del Tribunal de Nuremberg, en la madrugada del 16 de octubre de 1946. Sus últimas frases fueron “iDios proteja a Alemania!” (Keitel) y "Te saludo, Alemania mía" (Jodl). Las fotografías de sus cuerpos, tras la acción de la horca, junto a los de los ocho restantes condenados a muerte (Joachim von Ribbentrop, Ernst Kaltenbrunner, Alfred Rosenberg, Hans Frank, Wilhelm Frick, Julius Streicher, Fritz Saukel y Arthur Seyss-Inquart), en el tomo 7 y último de la Crónica militar y política de la Segunda Guerra Mundial, Ediciones Sarpe, Barcelona, 1980, pp. 170-174. Todos los cadáveres fueron introducidos en un horno crematorio del campo de concentración de Dachau, y las cenizas fueron dispersadas en las aguas del río Isar, el que baña Munich. 
al mando especialmente intrépido y resuelto del comandante, así como el valor de nuestros camaradas españoles, tuvo una importancia decisiva. ${ }^{23}$

El 30 de marzo señaló el punto de inicio del relevo de efectivos de la División Azul: 471 hombres de infantería partieron de Irún en dirección a Hof, donde estaba ubicado el nuevo centro de entrenamiento. El 4 de abril, se marchó la segunda; el 6 , la tercera, y el 8 , la cuarta, con la que tendría que quedar completado el primer punto pactado entre Asensio y Keitel. Muchos de entre ellos no iban ya a responder a los cánones deseados por el mando español e iban a ser repatriados, fenómeno que se incrementó sensiblemente en 1943. ${ }^{24}$ Todos quedaron concentrados en el nuevo campamento bávaro, donde recibieron el equipo alemán y, de igual manera que sus antecesores, prestaron juramento de fidelidad a Hitler «en su lucha contra el comunismo». Y comenzaron a retornar hombres a España, que no siempre encontraron la mejor de las situaciones posibles. Los primeros retornados, en enero, habían llegado con su uniforme de dril y una manta, en época de intenso frío. Y para los heridos y enfermos, la condición se complicaba, puesto que algunos hospitales militares se habían negado a atenderlos con el argumento de que eran falangistas y no militares.

Entrada la primavera, cercano ya el verano, las cosas habían cambiado poco. En Irún, muchos de aquellos hombres quedaron desatendidos. Algunos tuvieron que recurrir a los organismos oficiales, que tendieron a enviarlos al Consulado alemán de San Sebastián, a fin de que fuesen los alemanes quienes cambiasen la moneda que portaban y les diesen el apoyo necesario. De hecho, el cónsul Friedhelm Burbach, inicialmente entregó pequeños subsidios a heridos y enfermos, pero dada la multiplicación de las demandas, finalmente se inhibió. Ante ello, algunos ya ex divisionarios acudieron a minas y fábricas, pero la hostilidad manifiesta de sus compañeros llevó a los empresarios a prescindir de su trabajo y a negar nuevas contrataciones. En cuanto a Barcelona, los retornados también tuvieron problemas. No encontraban trabajo, y ni la Falange ni ningún otro organismo oficial se preocupó de su manutención y alojamiento. Finalmente, parte de ellos manifestaron al Consulado General su hartazgo y el deseo de retornar a Alemania como obreros. En Madrid, Stohrer supo lo que estaba pasando y se entrevistó con Serrano Suñer el 25 de julio, quien ya había sido

23 13-3-1942: Nota del Cuartel General de Hitler. PAAA; BM 6/9.

24 Para la crisis y muchas limitaciones del voluntariado, así como el trato infligido por el mando a los catalogados como «indeseables» (2.271 expedientes), véase RODRÍGUEZ JIMÉNEZ, José Luis: De héroes e..., hasta el punto de que en su artículo «Ni División Azul, ni División Española de Voluntarios: El personal forzado en el cuerpo expedicionario enviado por Franco a la URSS», en Cuadernos de Historia Contemporánea, 2009, 31 (2009), pp. 265-296, afirma -p. 276- que sólo 23.442 hombres (poco más de la mitad de los efectivos totales de la unidad) fueron alistados por las jefaturas provinciales de Milicias. Otra visión crítica de la unidad, con especial incidencia en el llamado «relato divisionario», las no siempre relajadas actitudes frente a la población civil rusa y la cuestión judía, la encontramos en los valiosos trabajos de Xosé Manoel NÚÑEZ SEIXAS, que, por su calidad, detallo en el apartado bibliográfico. Son obras que contrastan sensiblemente con lo que hasta la fecha ha realizado la bibliografía pro divisionaria, generalmente hagiográfica, pero no exenta de un alto nivel de erudición en la vertiente militar del tema, fundamentalmente de la mano de Carlos Caballero Jurado. Resulta también interesante el análisis, dada la profusión de documentación primaria utilizada, que hace el profesor Luis E. TOGORES, de la Universidad San Pablo-CEU, de la figura del general Agustín Muñoz Grandes (Muñoz Grandes. Héroe de Marruecos, general de la División Azul, La Esfera de los Libros, Madrid, 2007), y a quien agradezco, juntamente con el general Agustín Muñoz-Grandes Galilea, la cesión del archivo privado del general para el período de su estancia en la División Azul. 
informado y dio luz verde a su marcha a Alemania. Consecuentemente, la Embajada redactó una propuesta de contratación y a principios de agosto la envió al Ministerio de Exteriores, que no contestó. Ya el 1 de septiembre reiteró la petición, mediante nota recordatoria. Pero tan sólo dos días después, un inesperado cambio de titularidad en el Ministerio anuló el proyecto.

Ramón Serrano Suñer, menospreciado por los militares (le profesaban un odio visceral) y muy atacado por un sector del falangismo, que veían en él a un advenedizo, había jugado con la División Azul su última carta para conservar el poder. Ella había sido su valedora hasta que las armas alemanas en Rusia comenzaron a empantanarse. Entonces, perdió sus dos últimos asideros al poder: la cartera de Asuntos Exteriores y la presidencia de la Junta Política de Falange. La primera, retornaba al teniente general Francisco Gómez-Jordana y Souza, ${ }^{25}$ y la segunda, fue absorbida por un insaciable Franco. Aquello pasaba el 3 de septiembre de 1942, tras los dramáticos hechos de la Basílica de Nuestra Señora de Begoña, en Bilbao, que también costarían la cartera ministerial al general Varela y al coronel Valentín Galarza, titular de Gobernación, y la vida al falangista y ex divisionario Juan José Domínguez Ortiz. La Embajada alemana, aquella misma tarde informó a Berlín, y antes de medianoche relacionó la caída del ministro con los hechos de Begoña y valoró satisfactoriamente el ascenso del general Carlos Asensio a la cartera de Ejército y como «no desagradable» la de Jordana a la de Exteriores. Ya el 5, Stohrer recomendó a Berlín que la prensa hiciese comentarios amables a la acción de Serrano Suñer y dio por hecha la destitución del embajador Finat, en tanto que persona de confianza de aquél. Pero el embajador quería seguir en el cargo y se hizo el desentendido, hasta que el Consejo de Ministros del 14 de octubre nombró para el cargo al director del Departamento Político del Ministerio, Ginés Vidal y Saura, hombre de 52 años, soltero, que acumulaba más de treinta años de experiencia en la carrera diplomática y que dominaba el idioma alemán.

Vidal era un hombre meticuloso que muy pronto entró en plena sintonía con su ministro, decidido a conseguir la repatriación del general Muñoz Grandes (un intento anterior no había cuajado por oposición de Hitler). Tomó posesión de la Embajada el 17 de noviembre, pero no fue hasta el 2 de diciembre que puedo entregar sus credenciales a Hitler, sobre cuyas espaldas pesaba la Operación Antorcha, desarrollada con éxito tres semanas antes. Hitler se extendió en la situación de Rusia y abominó de los franceses, a la vez que, sin acritud, manifestó que, de haber tomado Gibraltar en su momento, los desembarcos hubiesen podido ser evitados. Entonces, Vidal pidió armamento alemán para defender España y manifestó que Muñoz Grandes era esperado «para llevar a cabo una importante misión». Hitler no mesuró sus palabras y dijo que accedía a la repatriación del general «de muy mala gana», y que sólo esperaba tener al frente de la División Azul a un hombre de la categoría de Muñoz Grandes.

Pero el general no tuvo un sucesor de altura. Emilio Estaban-Infantes Martín era una figura opuesta a él. Hombre de Estado Mayor, de poco carisma, que sucedía a un hombre de frente, popular entre la tropa y poco interesado en cuanto no fuese pri-

25 Así como de Serrano Suñer disponemos de sus memorias y de escritos varios, hasta cierto punto justificativos de su hacer, aunque, como ya he argumentado en otras ocasiones, en términos generales no falseadores de la realidad; del general Gómez-Jordana disponemos de una fuente más objetiva: sus Diarios, publicados en Burgos, en el 2002, por Editorial Dossoles. 


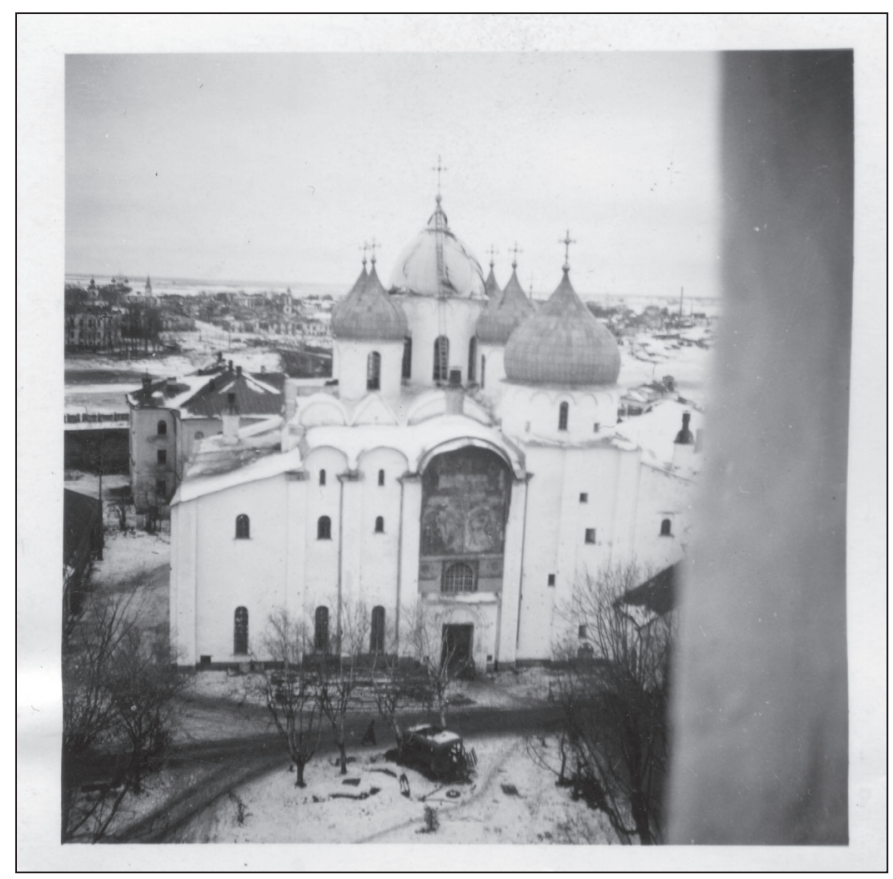

Iglesia, kremlim de Novgorod. Archivo Rodríguez Jiménez

mera línea de combate. Cuando Muñoz Grandes llegó a Madrid el 18 de diciembre fue recibido multitudinariamente. ${ }^{26}$ Pero aquel viernes iba a ver un hecho de mayor trascendencia: la abrupta destitución del embajador Stohrer, después de cinco años de servicio en España. El telegrama recibido, datado el 16 y firmado por Ribbentrop era contundente: el embajador von Moltke tomaría su relevo. Pero el motivo real no era transmitido: las trabas que Stohrer había puesto a un proyectado viaje de José Luis de Arrese, titular de la Secretaria General del Movimiento, a Alemania (tendría lugar pero sería un fiasco), en tanto que iniciativa de la odiada diplomacia paralela en Madrid. Pesaba también contra él el especial predicamento que había tenido con el defenestrado Serrano Suñer. La versión que dio, entre los medios alemanes en España, fue la de enfermedad (carta al cónsul general Jaeger). Fue objeto de homenajes y halagos diversos por sus muchos amigos españoles y marchó a Berlín a principios de 1943. ${ }^{27}$

26 Un grupo de jóvenes falangistas se dirigió a la Embajada británica y allí coreó consignas hostiles a la causa aliada, como había acaecido en junio de 1941. Pero había pasado un año y medio y las cosas habían cambiado: un contingente policial cargó contra ellos y abortó todo tipo de altercados.

27 Stohrer fue el principal embajador alemán en Madrid, tanto por el tiempo que ejerció el cargo (19371943), como por la ascendencia que tuvo sobre Franco y Serrano Suñer. Su antecesor, Faupel (1936-1937) se granjeó la enemistad de Franco por sus continuas intromisiones en temas que no eran de su incumbencia, y su sucesor, Moltke (1943), aunque muy eficiente, murió a los pocos meses de llegado a España. En cuanto a Hans Dieckhoff (1943-1944), el último de los embajadores del Tercer Reich en España, vio su acción limitada por la desfavorable marcha de la guerra. 


\section{Muñoz Grandes: la alternativa alemana a Franco}

El año 1942 presentó un hecho poco aclarado en el seno de la División Azul, que podría haber llegado a tener importantes repercusiones en España de no haber sido por el desfavorable desenlace de la guerra para Alemania. Un hecho que tiene en la persona del general Agustín Muñoz Grandes a su principal exponente, en tanto que fue él en quien Hitler se fijó para dar un golpe de timón a la política exterior española. Hombre más bien reservado, Muñoz Grandes odiaba a Inglaterra (lo demostró como gobernador militar del Campo de Gibraltar) y, por aquel entonces entendía que España debía adoptar una postura firme en contra de ella y, con la ayuda de Alemania, recuperar Gibraltar y entrar en la guerra. Precisamente, algo a lo que Franco, mucho más ambicioso que él y dejado llevar por sus sueños imperiales, se había negado en enero de 1941.

Hitler y Muñoz Grandes mantuvieron tres reuniones en total. La primera, el 1 de septiembre de 1941, la segunda, el 12 de julio de 1942, y la tercera, ya referida, el 13 de diciembre de aquel mismo año. Todas ellas tuvieron lugar en La Guarida del Lobo, su cuartel general en Rastenburg, Prusia Oriental. La primera fue una reunión meramente protocolaria. Sabemos poco sobre ella, por falta de actas y documentación colateral, pero sí que Muñoz Grandes anunció que la División Azul estaba preparada para el combate y sus hombres ansiosos para contribuir a la aniquilación del bolchevismo. En cuanto a Hitler manifestó que el Ejército Rojo sería capaz todavía de una dura y larga resistencia, después de la cual se derrumbaría. La segunda reunión, en julio de 1942, fue la que tuvo un marcado carácter político, y a pesar de que las fuentes que se conservan son también escasas, sabemos que giró en torno a la situación del poder en España y en la posibilidad de dejar a Franco relegado a una simbólica presidencia de Estado en tanto que Muñoz Grandes asumiría la jefatura del Gobierno y, con ello, predispondría a España para entrar en la guerra. No sabemos desde cuándo tal posibilidad rondaba en la cabeza de Hitler, pero se da la circunstancia de que ya el 15 de junio supo que el general se había pronunciado en favor de la guerra. Tal circunstancia, lo llevó a solicitar a Franco, por vía del almirante Wilhelm Canaris, su permanencia en el frente, dado que ya había partido hacia allí quien debería sustituirlo. ${ }^{28}$ Hay que especificar, sin embargo, que tanto los preparativos del encuentro como parte de la información que disponemos sobre él parten de los informes de la diplomacia paralela alemana, el Dienstelle Ribbentrop, el ya referido conjunto de hombres jóvenes a las órdenes directas de Ribbentrop, insertos en las Embajadas para controlar la labor de la diplomacia de carrera. Pero dado que las informaciones sobre

28 Los profesores Kleinfeld y Tambs, La División española...., pp. 283-291, se centran en los antecedentes del encuentro y en los detalles del mismo; del mismo modo que los referiría el profesor Klaus-Jörg RUHL, en su obra Franco, Falange y Tercer Reich. España en la Segunda Guerrra Mundial, Madrid, Ediciones Akal, 1986, pp. 110-113. Véase también, MORENO JULIÁ Xavier: La División Azul..., pp. 139, 179, 249, 462 y 466. Sobre la entrevista de 1942 disponemos fundamentalmente de tres fuentes primarias. Concretamente, un informe del miembro del Dienstelle Ribbentrop Rudolf Likus de 13 de julio (ADAP, E-III); un telegrama del subsecretario de Estado Woermann a Stohrer del 25 (PAAA, BM); y un informe del embajador Stohrer de 31 de agosto con las declaraciones que cinco días antes hizo un oficial español apellidado Monteys (probablemente el intérprete teniente José Jaime Monteys, en tanto que el informe detalla que hablaba alemán) a «una persona de total confianza» del embajador (PAAA, StS). 
el encuentro tuvieron también cabida dentro de la diplomacia oficial, cabe darles crédito. Además, no hay que olvidar el contexto en el que el general español se movía, al mando de una unidad muy superior a cualquiera de las españolas del momento, y sus reiteradas críticas al conservadurismo de Franco. ${ }^{29}$

\section{Las interacciones hispano-alemanas en el año 1943, la repatriación de la División Azul y epílogos frustrados}

El año 1943 fue el último de permanencia de la División Azul en el frente. El 10 de febrero vivió la tragedia de Krasnyj Bor, con la muerte de 1.125 de sus hombres en un solo día, casi la cuarta parte de los que morirían en dos años. Después, la lucha quedaría limitada a acciones puntuales de la infantería y a la descarga de proyectiles artilleros. En julio, con la detención de Mussolini, se hundió el fascismo, y tuvo lugar el último ataque alemán en Rusia, en Kursk, punta avanzada del sector central, rápidamente neutralizado y superado por los rusos. Después, algunos avances puntuales alemanes (reconquista de Jarkov), también rápidamente frustrados. La iniciativa militar quedaba totalmente en manos soviéticas, y en aquel contexto, el 12 de octubre, dos años justos después de haber llegado al frente, la División Azul lo abandonó.

Hans Adolf von Moltke llegó a Madrid el 11 de enero de 1943 en el expreso de Irún y ejerció su cargo hasta el 22 de marzo, día de su muerte, a raíz de un ataque de apendicitis. Poco más de dos meses de una labor ingente, de un hombre de elevada formación y posición social, y que supo conectar con Franco. ${ }^{30}$ Así, el día de la presentación de credenciales (22 de enero), la entrevista, que debía durar unos quince minutos, se alargó durante casi una hora. Y con él llegó un nuevo primer secretario de Embajada, Andor Hencke, en sustitución de Hans Heberlein, retornado a Berlín con Stohrer. Unos días antes, el 15, se había reunido con Muñoz Grandes, quien se manifestó resentido con Franco: había quedado en situación de disponibilidad forzosa, en su nuevo empleo de teniente general, y Hitler no había recibido aún la requerida respuesta al empleo del armamento alemán. Pero la consecución más importante de Moltke fue precisamente la firma del Protocolo Secreto Germano-Español el 12 de febrero, documento que, finalmente, obligaba a España a la utilización del armamento que iba a recibir de Alemania contra un plausible ataque anglo-norteamericano a la Península o al Protectorado español de Marruecos. Con él, quedaba por fin cerrado el capítulo abierto en diciembre del año anterior.

Muerto Moltke, el 30 de abril de 1943 presentó sus cartas credenciales un nuevo embajador: Hans Heinrich Dieckhoff. El último representante alemán en Washington (1937-1938) vino concienciado de que, dada la difícil situación por la que su país atravesaba, debería actuar sobre la base de ofrecer tanto como pudiese y pedir lo

29 Una comparación entre los términos de la diplomacia de carrera y la «paralela» sobre la cuestión, en MORENO JULIÁ Xavier: «¿Quiso Hitler derribar a Franco?», Clío revista de historia, 56 (2006), pp. 36-43.

30 Para la actuación del embajador Moltke resulta fundamental la consulta de la exhaustiva obra de SÁENZ-FRANCÉS Emilio: Entre la Antorcha y la Esvástica. Franco en la encrucijada de la Segunda Guerra Mundial, Madrid, Actas Editorial, 2009. Una obra que, entre otros méritos (memorias de Hans Lazar y del embajador Stohrer) recoge el diario personal del embajador durante su estancia en Madrid. 
menos posible. Entretanto, Berlín había visto el relevo de Weizsäcker por el barón Gustav Adolf Steengracht, así como del subsecretario Woermann por Andor Hencke, recientemente retornado de Madrid a raíz del fallecimiento de Moltke. De hecho, la guerra proseguía y, día a día, se complicaba para Alemania, que vio como aquella primavera y verano quedaron marcados por los hechos de Túnez, Kursk e Italia (primero, la insular, y después la continental). Fueron grandes reveses que Alemania intentó contrarrestar con un proceso de intensificación de la propaganda que, para el caso de la Península, dio lugar a la creación del Comité de España-Portugal, en el seno del Auswärtiges Amt. Lo presidiría Hans Heberlein, el antiguo primer secretario de la Embajada en Madrid, y desarrollaría su actividad a partir de la celebración de sesiones monográficas de discusión sobre temas candentes de las interacciones entre Alemania y España y Portugal. Uno de ellos fue la División Azul.

Pero, por mucho que Alemania se esforzase, nada iba a poder neutralizar la gran impresión que entre el Gobierno español y la opinión pública del país tuvo el hundimiento de Mussolini y el fascismo ( 25 de julio). Fue precisamente entonces cuando el embajador norteamericano, profesor Carlton Hayes, solicitó de Franco la repatriación de la División Azul, a lo que unió el retorno a la neutralidad (abandono de la «no beligerancia») y el final de la acción propagandística de la prensa en favor del Eje. Era el miércoles 28 de julio de 1943, y la vida de la División comenzaba su cuenta atrás. Franco, flemático como siempre pero no por ello un tanto alarmado, reunió el Consejo Supremo de Guerra, del que obtuvo la aprobación de su propuesta de retirada gradual. Y ordenó la neutralidad informativa. Pasados unos días, el 20 de agosto, fue el embajador británico, sir Samuel Hoare, quien manifestó el deseo de su Gobierno de repatriación de la División Azul. ${ }^{31}$ La pinza, aunque innecesaria, era perfecta, y comenzó una ardua tarea para el ministro Jordana y su embajador en Berlín, el sagaz Ginés Vidal. Serían también importantes los buenos oficios del duque de Alba, en Londres, y Juan Francisco de Cárdenas, en Washington.

Sin el apoyo del Ministerio del Ejército (el germanófilo general Asensio no quería la repatriación de la División Azul), el 23 de agosto Jordana se reunió con Vidal en San Sebastián para perfilar las directrices a seguir ante Alemania para conseguir la retirada del frente y posterior repatriación de la unidad. ${ }^{32}$ Fue así como comenzó a moverse el engranaje que llevaría a su final. Ya el 24 de septiembre, por iniciativa de Franco, el Consejo de Ministros decidió que resultaba «indispensable retirar de línea

31 Para Hoare, su estancia en España no fue más que un elemento colateral en su carrera política. Difícilmente conectó con la forma de hacer y pensar de los españoles, y siempre mantuvo una actitud de distanciamiento y no disimulada superioridad. La frase «país de salvajes» espetada a Serrano Suñer, no deja de ser la manifestación de una forma de entender el país. Por todo ello, las memorias de su paso por España, aunque importantes, deben ser leídas con el necesario distanciamiento. Apuntar aquí que en su acción tuvo la suerte de contar con el conocimiento del país del decano de los embajadores, el portugués Pedro Teotónio Pereira, hombre sumamente inteligente y más sensible a la realidad española que él.

32 La actitud de Asensio respondía a la de la mayoría germanófila en el Gobierno. En cuanto al general Jordana, más que aliadófilo (de hecho, no creo que fuese tal), era un hombre pragmático que entendió que, en aquellos momentos, las necesidades del país pasaban por una sincera apertura al campo aliado, lo que le costó no pocos disgustos y desencuentros. Decir aquí que la postura de Franco respecto a la guerra, anclada en la ambivalencia, frenaba la acción de Jordana, quien llegó al punto de amenazarlo con la dimisión, harto como estaba de su actitud y la de muchos de los miembros del Gabinete, así como de las bravatas de Samuel Hoare y de las peticiones, contundentes aunque menos agresivas, de Carlton Hayes. 
a la División Azul, y hacerlo lo antes posible, puesto que el cambio de estación sería inmediato». Y ya el 1 de octubre de 1943, en Berlín, Vidal comunicó a Steengracht la decisión española y, en Madrid, el tradicional banquete anual en honor del cuerpo diplomático vio como Franco se detuvo y suspiró un «¡Gran Bretaña, Gran Bretaña!» ante el consejero británico de Embajada, Yenken, y como utilizó la palabra «neutralidad» para definir la posición internacional de España. Informado el Foreign Office de las intenciones de España por el Duque de Alba, el 2 Jordana las expuso al embajador Dieckhoff.

A partir de aquel momento, la maquinaria alemana, con acritud, comenzó a moverse: el 3 de aquel mes de octubre, la Wehrmacht recibió la petición española; el 6, Ribbentrop dictó a Steengracht una nota para Vidal y otra para Jordana, que el 11 Dieckhoff les entregó. Al día siguiente, hubo un cruce de cartas entre Jordana y Vidal, con la retirada de la División Azul como telón de fondo: el ministro informaba de su entrevista con Dieckhoff y Vidal manifestaba que la unidad acababa de iniciar su retirada del frente de guerra. Justamente se cumplían dos años del inicio de la acción militar de la División Azul: casualidades -o imposiciones- del destino.

Las cosas (los quebraderos de cabeza, de hecho) hubieran podido acabar con la repatriación de la División Azul de no haber sido por el miedo español a proceder a una retirada y repatriación sin contrapartidas. Pero la unidad luchaba muy lejos, rodeada de fuerzas alemanas, y las reacciones de frustración eran imprevisibles. Además, el Consejo de Ministros seguía anclado en su tradicional germanofilia, y entendía que no se podía arrancar, sin más, el apoyo bélico a Alemania. Fue por ello que el ministro Asensio propuso -y consiguió, con el beneplácito de Franco y la contrariedad de Jordana- la configuración, en el propio frente, de una unidad de pequeñas dimensiones (al final sólo dispondría de 2.269 hombres) destinada a reemplazar a la División Azul. Pero los Aliados, triunfantes ya en todos los campos de batalla, pronto supieron de su existencia y la interpretaron como una afrenta que debería ser inmediatamente subsanada por los españoles.

La llamada Legión Azul luchó en enero de 1944 y vivió la brutal retirada del Ejército alemán en el norte ruso. Sirvió de tapadera para la repatriación de la División Azul y poco más. En abril llegaron sus últimos hombres a España. ${ }^{33}$ Quedaron entonces al lado de Alemania unos centenares de combatientes, pero ya no como representantes de España, cuyo Gobierno decidió la pérdida de su nacionalidad, sino como miembros del Ejército alemán. En él lucharon, o en las Waffen SS, pero aquélla es ya otra historia, donde los datos se mezclan y la memoria siempre falla. ${ }^{34}$ Unos quinientos prisioneros españoles quedaron en el Gulag, pero por intereses del Gobierno español, que se enganchó a la Doctrina Truman en el año 1947, permanecieron allí hasta el año 1954, muerto ya Stalin. Barcelona y su puerto los acogerían el 2 de abril,

33 A punto estuvieron de no llegar, pues de haber prosperado las propuestas del mariscal Walter Model, hubiesen sido utilizados como elemento de barrera frente al avance soviético. Hitler tuvo una visión más amplia de la situación y optó por adelantarse a la petición española y dio la orden de retirada del frente y repatriación.

$34 \mathrm{Su}$ estudio prácticamente ha quedado limitado a la labor de la historiografía «divisionista», esto es, abiertamente simpatizante de la causa divisionaria en el frente del Este. Es una historiografía que, al igual que la «revisionista» de otros países (a destacar la obra del sueco Erik Norling), acostumbra a detenerse en el detalle y a hacer una lectura unilineal de los acontecimientos generales. 
un viernes, en un acto del que disponemos de metraje cinematográfico y de abundante material de hemeroteca. Pero Franco llegó al punto de negarles la posibilidad de ser recibidos con un mínimo de pompa en Madrid, por medio del acordonamiento por la policía del tren que debía llevarlos hasta allí. Era el Franco amigo de Occidente, que nada quería tener que ver con el Franco amigo de la Alemania de Hitler. ${ }^{35}$

\section{Conclusiones}

Las interacciones hispano-germanas durante el período comprendido entre 1936 y 1945 configuran, por su interés y la multiplicidad de elementos en juego, un apartado prácticamente inagotable para la historiografía de ambos países. No en vano conjugan una guerra civil con otra europea que pasó a mundial, eventos cruciales de nuestro pasado siglo. Si aminoramos el período con la supresión de los cuatro primeros años, como es el caso de este artículo, que inicia su recorrido en 1940, tampoco nos quedamos cortos en la cantidad de interacciones habidas. Así, una España destrozada pero con un Régimen ansioso de verla elevada a la categoría de potencia en una Europa regida por el Tercer Reich, dio mucho de sí en el ámbito de sueños imperiales (junio a octubre de 1940), de frustraciones y exigencias esquivadas (noviembre de 1940 a junio de 1941), así como de colaboraciones limitadas (julio de 1941 a octubre de 1943), silenciadas (noviembre de 1943 a marzo de 1944) y finalmente negadas (abril de 1944 a mayo de 1945). Colaboraciones que tuvieron en la División Azul y sus sucedáneos (Legión Azul y clandestinos) a sus elementos configuradores, y que hacen de aquella unidad un todo complejo y repleto de matices, que hemos intentado sintetizar en las páginas que preceden a esta reflexión final.

En suma, hemos analizado realidades de hace ya setenta años pero que siguen y seguirán marcando nuestra memoria colectiva, en tanto que definidoras de una época muy especial, en la que las voluntades quedaban apresadas por los dictados de una guerra atroz. Con su final, una nueva etapa de interacciones se abriría entre España y Alemania (a partir de 1949, fundamentalmente con la República Federal), muy distinta de la anterior, pero con algunos elementos en común, como el del destino de los prisioneros de ambos países en la Unión Soviética o los subsidios a recibir por los ex miembros de la División Azul lisiados o los derechohabientes de los fallecidos. Pero esa es ya otra historia, cuyo análisis en detalle escapa al objeto de este artículo.

\section{Bibliografía}

BURNS MARAÑÓN, Jimmy: Papá espía. Amor y traición en la España de los años cuarenta, Barcelona, Debate, 2010.

GODA, Norman J. W.: Y mañana ... el mundo. Hitler, África Noroccidental y el camino hacia América, Madrid, Alianza Editorial, 2002.

35 Para el último año de la División Azul y sus epígonos, véase, entre otros, MORENO JULIÁ Xavier: La División Azul..., pp. 184-209 y 269-309. 
GÓMEZ-JORDANA SOUZA, Francisco: Milicia y diplomacia. Diarios del Conde de Jordana, 1936-1944, Burgos, Editorial Dossoles, 2002.

KLEINFELD Gerald R.; TAMBS, Lewis A.: La División española de Hitler. La División Azul en Rusia, Madrid, Editorial San Martín, 1979.

MORADIELLOS, Enrique: Franco frente a Churchill. España y Gran Bretaña en la Segunda Guerra Mundial (1939-1945), Barcelona, Ediciones Península, 2005.

MORENO JULIÁ, Xavier: La División Azul. Sangre española en Rusia, 1941-1945, Barcelona, Editorial Crítica, 2004. Hitler y Franco. Diplomacia en tiempos de guerra (1936-1945), Barcelona, Editorial Planeta, 2007.

NÚÑEZ SEIXAS, Xosé Manoel: Imperios de muerte. La guerra germano-soviética, 1941-1945, Madrid, Alianza Editorial, Madrid, 2007. Artículos en español: «¿Un nazismo colaboracionista? Martín de Arrizubieta, Wilhem Faupel y los últimos de Berlín (1944-45)», en Historia Social, 51; Valencia, 2005, pp. 21-47. «Los vencedores vencidos: La peculiar memoria de la División Azul, 1945-2005. Pasado y Memoria», en Revista de Historia Contemporánea, 4, Alicante, 2005, pp. 83-113. «¿Eran los rusos culpables? Imagen del enemigo y políticas de ocupación de la División Azul en el frente del Este, 1941-1944», en Hispania. Revista española de Historia, LXVI, 223, Madrid, mayo-agosto 2006, pp. 695-750. «El Tercer Reich, la Wehrmacht y la División Azul, 1941-1945: Memoria e imágenes contrapuestas»; en Ayer, 69, Madrid, 2008, pp. 47-72. «iTestigos o encubridores? La División Azul y el holocausto de los judíos europeos: entre historia y memoria»; en Historia y política, 26; Madrid, julio-diciembre 2011, pp. 259-290.

OVERY, Richard: Russia's War, 1941-1945, Londres, Penguin Books, 1998.

PAYNE, Stanley G.: El régimen de Franco, 1936-1975, Madrid, Alianza Editorial, 1987. Franco y Hitler. España, Alemania, la Segunda Guerra Mundial y el Holocausto, Madrid, La Esfera de los Libros, 2008

PRESTON, Paul: Franco «Caudillo de España», Barcelona, Grijalbo, 1994,

RODRÍGUEZ JIMÉNEZ, José Luis: De héroes e indeseables. La División Azul, Madrid, Editorial Espasa-Calpe, 2007. «Ni División Azul, ni División Española de Voluntarios: El personal forzado en el cuerpo expedicionario enviado por Franco a la URSS», en Cuadernos de Historia Contemporánea (Madrid, 2009), pp. 265296.

ROS AGUDO, Manuel: La guerra secreta de Franco (1939-1945), Barcelona, Editorial Crítica, 2002. La gran tentación. Franco, el Imperio Colonial y los planes de intervención en la Segunda Guerra Mundial, Madrid, Styria, 2008. Franco/Hitler 1940: de la Gran Tentación al Gran Engaño, Madrid, Arco/Libros, 2009.

RUHL, Klaus-Jörg: Franco, Falange y «Tercer Reich». España en la Segunda Guerra Mundial, Madrid, Ediciones Akal, 1986.

SÁENZ-FRANCÉS, Emilio: Entre la Antorcha y la Esvástica. Franco en la encrucijada de la Segunda Guerra Mundial, Madrid, Actas Editorial, 2009. 
SERRANO SUÑER, Ramón: Entre Hendaya y Gibraltar, Madrid, Editorial Epesa, 1947 (edición revisada y ampliada en Barcelona, Editorial Nauta, 1973). Entre el silencio y la propaganda, la Historia como fue. Memorias, Barcelona, Editorial Planeta, 1977.

THOMÀS, Joan Maria: La Falange de Franco. Fascismo y fascistización en el régimen franquista (1937-1945). Barcelona, Plaza\&Janés Editores, 2001.

TOGORES, Luis E.: Muñoz Grandes. Héroe de Marruecos, general de la División Azul, Madrid, La Esfera de los Libros, Madrid, 2007.

TUSELL, Javier: Franco, España y la Segunda Guerra Mundial. Entre el Eje y la neutralidad, Madrid, Ediciones Temas de Hoy, 1995.

WIGG, Richard: Churchill y Franco. La politica británica de apaciguamiento y la supervivencia del régimen, 1940-1945, Barcelona, Debate, 2005. 